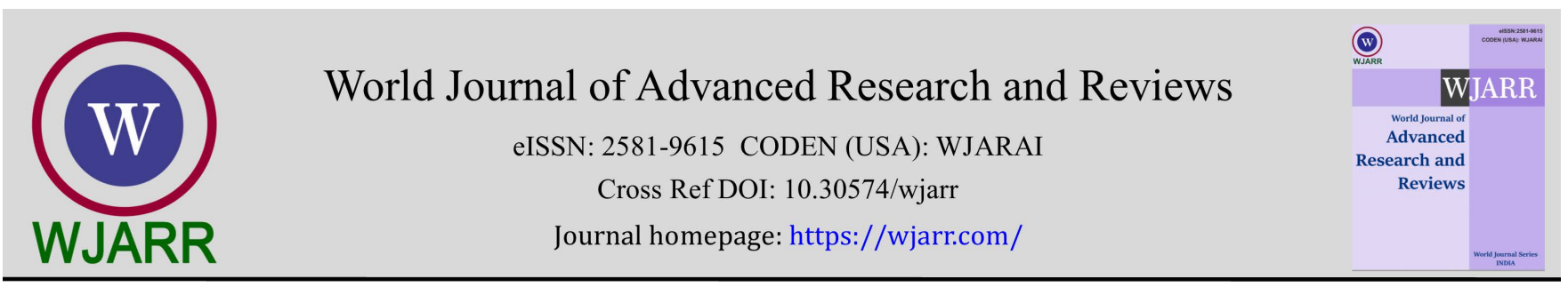

(RESEARCH ARTiClE)

Check for updates

\title{
Effect of Solanum gilo leaf extract on some haematological indices of albino Wistar rats
}

Nsimah Monday Essien 1, Justina Nwadimma Nwangwa 2, Charles Cyprian Mfem 2, Johnbull Martins Uket 2 and Efiok Aniekan Archibong 2,*

1 Department of Human Nutrition and Dietetics, University of Calabar, Calabar PMB 1115, Nigeria.

2 Department of Human Physiology, University of Calabar, Calabar PMB 1115, Nigeria.

World Journal of Advanced Research and Reviews, 2021, 12(01), 108-111

Publication history: Received on 16 August 2021; revised on 30 September 2021; accepted on 02 October 2021

Article DOI: https://doi.org/10.30574/wjarr.2021.12.1.0463

\begin{abstract}
Solanum gilo (eggplant) is an edible vegetable whose leaf is reported to possess numerous medicinal properties due to its rich constituents. Against this backdrop, there is possibility that its consumption may have effect on haematological indices. Therefore this research sought to assess the effect of Solanum gilo leaf diet on some haemotological indices of albino wistar rats. About twenty four (24) albino wistar rats weighing between 120-150mg were randomly assigned into four groups of six animals each. Each rat was allowed to drinking water ad labitum. Control group received normal rodent chow while group 2 was fed 5\% Solanum gilo diet. Group 3 was fed 10\% Solanum gilo diet and group 4 received $20 \%$ Solanum gilo diet. The different diets were prepared by mixing different proportions of ground S. gilo leaves with rodent chow. Automated blood cell analyzer (Model PCE 210, Japan) was used for analysis of haematological parameters. Preliminary study on its proximate composition, showed the appreciable presence of crude fat, protein, fibre and carbohydrate. Consumption of S. gilo caused significant improvement in some blood parameters; notably packed cell volume (PCV), white blood cell (WBC) and platelet counts. Hence, eggplant is a nutritious vegetable with healing, the therapeutic and immunity properties. If exploited in human diet has the potentials of improving quality of life.
\end{abstract}

Keywords: Solanum gilo; Diet; Haematology; Nutrient; Wistar rats

\section{Introduction}

Before the advent of orthodox medicine, man depended on plants for their medicinal and nutritional needs. Herbs predated man's history thus the dependence of man on herbs goes beyond the dawn of history. They supply the body with minerals, vitamins and certain hormone precursors in addition to protein and energy [1].

Solanum gilo (Eggplant) is a member of the solanaceae family and the genus Solanum [2]. It is grown worldwide for its edible fruit. The egg-shaped, white varieties of its fruits are also called garden eggs. Apart from the commercial value of S. gilo, it can serve as an important source of micronutrients vitamins and proteins which can be used to address potential deficiencies [3]. Studies have also reported wide biological and pharmacological activities attributed to Solanum species, which range from weight reduction to treatment of several ailments including asthma, skin infections and constipation [2].

\footnotetext{
* Corresponding author: Efiok Aniekan Archibong

Department of Human Physiology, University of Calabar, Calabar PMB 1115, Nigeria.
}

Copyright (C) 2021 Author(s) retain the copyright of this article. This article is published under the terms of the Creative Commons Attribution Liscense 4.0. 
With many studies reporting its beneficial effect, there is possibility of Solanum gilo affecting many haematological indices. Hence this research was geared towards assessing the effect of Solanum gilo leaf diet on some haemotological indices of albino wistar rats.

\section{Material and methods}

\subsection{Collection and preparation of Solanum gilo ethanolic leaf extract}

Fresh leaves of Solanum gilo were collected from a farm located in Calabar, Nigeria. They were rinsed severally with clean water to remove debris and other particles followed by distilled water. Thereafter, they were dried under shade. The leaves were ground to powder. After being weighed, the powder was soaked in 80\%. Ethanol in the ratio of $1: 4$ and allowed for 48 hours before filtration. The filtrate was concentrated using a rotator evaporator. The temperature of the evaporator was maintained below $30^{\circ} \mathrm{C}$. This extract was used for determination of the proximate concentrations of Solanum gilo leaf extract.

\subsection{Experimental animals}

In total, 24 albino wistar rats weighing between 120-150 mg were used for this study. They were kept in a wellventilated room to room temperature $(28 \pm 2 \mathrm{C})$ and humidity ( $85 \pm 5$ percent). The animals were kept in a normal $12 / 12$ light/dark cycle and allowed to acclimatize for two weeks prior to the commencement of the experiments proper and were handled in accordance to the guidelines governing the use of experimental animals. They were randomly assigned into four groups of six animals each. Each rat was allowed to drinking water ad labitum. Control group received normal rodent chow while group 2 was fed 5\% Solanum gilo diet. Group 3 was fed 10\% Solanum gilo diet and group 4 received $20 \%$ Solanum gilo diet.

\subsection{Preparation of experimental diets and administration}

The Solanum gilo diets were prepared by mixing proportions of it with normal rodent chow. Three of such diets were prepared; 5\% diet (which was composed of 5\% ground Solanum gilo powder and 95\% normal rodent chow) was fed to group 2, 10\% diet (composed of 10\% ground Solanum gilo powder and $90 \%$ normal was fed to Group 3) rodent chow) and $20 \%$ diet (composed of $20 \%$ Solanum gilo powder and $80 \%$ normal rodent chow) was fed to group 4.

\subsection{Animals scientific and collection of blood samples}

The feeding of the different groups with their respective diets lasted for 21days after blood samples were obtained/collected and haematological parameters estimated. Prior to their sacrifice, the animals were footed overnight before being anesthetized with the use of chloroform. Serum was obtained by cardiac puncture with the use of a cardiac atheter into EDTA bottle for haematological analysis.

\subsection{Measurement of blood parameters}

Automated blood cell analyzer (Model PCE 210, Japan) was used. The Serum in the EDTA sample bottles was thoroughly mixed to avoid blood clothing. The machine was switched on with its specific diluents and haemolysate and allowed to boot. When the machine indicated readiness, each sample bottle was raised for the probe of the machine to such the required volume of the blood for the test. The measurements were automatically taken by the machine.

\subsection{Proximate analysis of Solanum gilo}

The proximate constituents of Solanum gilo were analysed using standard methods [4].

\subsection{Statistical Analysis}

Data obtained were analyzed using analysis of variance (ANOVA) followed by a post hoc test (least square difference (LSD) test) to determine significant difference between means. The analysis was done with an SPSS 18 statistical package. The values were presented as mean \pm SD. 


\section{Results and discussion}

Table 1 Proximate composition of Solanium gilo leaves (\% wet weight)

\begin{tabular}{|l|c|c|c|c|c|c|c|}
\hline Samples & Moisture & Protein & Crude fat & Crude fiber & Ash & Carbohydrate & Caloric value \\
\hline Solanum gilo & 64.53 & 5.25 & $\begin{array}{c}3.25 \\
\pm 0.07\end{array}$ & $\begin{array}{c}1.69 \\
\pm 0.01\end{array}$ & $\begin{array}{c}1.33 \\
\pm 0.03\end{array}$ & $\begin{array}{l}23.63 \\
\pm 0.04\end{array}$ & $130.73 \mathrm{kcal}$ \\
Leaves & \pm 0.14 & \pm 0.03 & \pm 0.03 & \\
\hline
\end{tabular}

Results are presented as mean \pm SD N $=$ No. of determinants

From the results obtained Solanum gilo leaves proximate analysis showed the presence of high moisture and carbohydrate contents. Due to its high moisture content, it should be stored in a cool storage to prevent spoilage. The high carbohydrate content depicts that $S$. gilo has high caloric value. It also contains proteins and crude fat as well as ash. This significant presence of these nutrients shows that it could be eaten to protect against malnutrition, scurvy and other ascorbic acid deficiency ailments. This analysis also revealed the presence of crude fiber in $S$. gilo and this is beneficial because high level of dietary fiber in leafy vegetables are reported to be advantageous due to their active role in the regulation of intestinal transit, increasing dietary bulk and increasing fecal consistency as a result of their ability to absorb water. Hence this study estimated that the proximate composition of Solanum gilo leaves are good source of nutrient and can be exploited in human nutrition.

Table 2 Haematological parameters of the experimental fed the different S. gilo diets

\begin{tabular}{|l|l|l|l|l|c|c|}
\hline GROUPS & $\begin{array}{l}\text { R.B.C. } \\
(\mathbf{1 0} / \mathbf{l})\end{array}$ & P.C.V (\%) & $\begin{array}{l}\text { W.B.C } \\
\mathbf{( 1 0} / \mathbf{l})\end{array}$ & $\begin{array}{l}\text { Platelet } \\
\mathbf{( 1 0} / \mathbf{l})\end{array}$ & $\begin{array}{l}\text { Neutrophil } \\
\mathbf{( 1 0} / \mathbf{l})\end{array}$ & $\begin{array}{l}\text { Lymphocyte } \\
\mathbf{( 1 0} / \mathbf{l})\end{array}$ \\
\hline Control & $5.74 \pm 0.1$ & $47.8 \pm 0.5$ & $10.19 \pm 0.5$ & $703 \pm 0.2$ & $47.40 \pm 2.2$ & $43.2 \pm 2.3$ \\
\hline $5 \%$ diet & $4.78 \pm 0.4$ & $50.00 \pm 0.1$ & $9.80 \pm 0.2$ & $704 \pm 0.4$ & $35.33 \pm 1.8$ & $50.21 \pm 2.3$ \\
\hline $10 \%$ diet & $5.33 \pm 03$ & $48.00 \pm 0.2$ & $11.20 \pm 0.6$ & $843 \pm 0.5$ & $36.43 \pm 2.1$ & $45.3 \pm 2.8$ \\
\hline $20 \%$ diet & $5.38 \pm 0.2$ & $49.60 \pm 0.3$ & $9.61 \pm 0.3$ & $833 \pm 0.2$ & $33.21 \pm 2.1$ & $44.21 \pm 1.8$ \\
\hline
\end{tabular}

Consumption of $S$. gilo caused significant improvement in some blood parameters. There was significant improvement in the red blood cell (RBC) count, packed cell volume (PCV) of the animals fed the different Solanum gilo diets. This improvement implies an enhancement in the oxygen-carrying capacity of blood of the experimental animals. The PCV also known as haematocrit is the volume percentage of red blood cells in blood measurement. On red blood cells are pigments known as haemoglobin which help in the transportation of oxygen to different parts of the body. Therefore improvement in the RBC count as well as the PCV implies a boost in the circulation of oxygen to different parts of the body.

Also, there were improvements in the white blood cell (WBC) and lymphocyte counts in the animals fed the different Solanum gilo diets compared to the control. This implies a boost in immunity because the immune system relies on white blood cells that produce antibodies to combat bacteria, viruses as well as other invaders [5]. Thus consumption of Solanum gilo diets showed potentials of boosting immunity as observed in the improvement of WBC and lymphocyte counts.

Platelets play a vital role in healing role in healing and recovery of the body. As observed in this study, the platelet count was improved in the group fed the S. gilo diets when compared to control. This denotes that Solanum gilo has healing potentials

\section{Conclusion}

This research shows that Solanum gilo (eggplant) is a nutritious vegetable with healing, the therapeutic and immunity properties. If exploited in human diet has the potentials of improving quality of life. 


\section{Compliance with ethical standards}

\section{Acknowledgments}

We wish to specially acknowledge Mr Udemeobong Okon for his assistance in proof reading this article.

Disclosure of conflict of interest

The authors have no conflicts of interest.

\section{Statement of ethical approval}

Approval for this study was obtained from the Faculty Animal Ethics Committee of Faculty of Basic Medical Sciences, University of Calabar with Protocol number 018PY40334.

\section{References}

[1] Ndlovu J, Afolayan AJ. Nutritional analysis of the South African wild vegetable Corchorus olitorius L. Asian J. Plant Sci. 2008; 7: 615-618.

[2] Agoreyo BO, Obansa ES, Obanor EO. Comparative nutritional and phytochemical analysis of two varieties of Solanium melongena. Sci World J. 2012; 7: 5-8.

[3] Chinedu SN, Olasumbo AC, Eboji OK, Emiloju OC, Arinola OK, Dania DI. Proximate and phytochemical analysis of Solanium aethiopicum L and Solanium macrocarpon L. fruits. Research Journal of Chemical Sciences. 2011; 1: 6371.

[4] Hart FL, Fisher HJ. Introduction-General methods for proximate and mineral analysis. In: Modern Food Analysis. Springer, Berlin Heidelberg. 1971.

[5] Nicholson LB. The immune system. Essays in Biochemistry. 2016; 60: 275-301. 